Jurnal Konstruksi Hukum | ISSN: 2746-5055

Vol. 2, No. 1, Januari 2021 Hal. 52-56 | Tersedia online di https://www.ejournal.warmadewa.ac.id/index.php/jukonhum

DOI: https://10.22225/jkh.2.1.2967.52-56

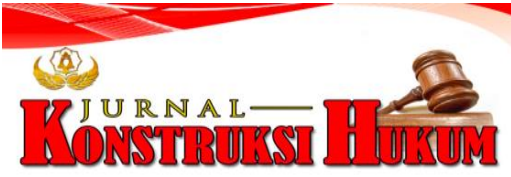

\title{
PARTISIPASI MASYARAKAT DALAM PEMILIHAN UMUM SERENTAK TAHUN 2019 Di KELURAHAN UBUNG, KECAMATAN DENPASAR UTARA, KOTA DENPASAR
}

\author{
I Gusti Agung Ayu Diah Aprillia, I Wayan Arthanaya, Luh Putu Suryani \\ Fakultas Hukum Universitas Warmadewa, Denpasar-Bali, Indonesia
}

\begin{abstract}
Abstrak
Pemilu merupakan suatu rangkaian kegiatan dalam pemungutan suara secara demokratis. Berkenaan dengan hal ini, maka pemilu diatur dalam Undang-Undang Nomor 7 Tahun 2017 disini dijelaskan bahwa bagaimana partisipasi masyarakat Kelurahan Ubung dalam rangka mengikuti proses pemilu tahun 2019. Penelitian ini bertujuan untuk mengetahui sistem penyelenggaraan pemilu menurut Undang-Undang No. 7 Tahun 2017 dan mengetahui pelaksanaan pemilu di Kelurahan Ubung. Jenis penelitian yang digunakan adalah penelitian empiris. Penelitian ini dilaksaknakan dengan cara langsung terjun ke lokasi penelitian yang bertempat di Kelurahan Ubung. Hasil penelitian menunjukan bahwa tahap dalam keikutsertaan rakyat kelurahan ubung adalah: dalam proses pemilu maka dapat diklasifikasikan menjadi 3 (tiga) tahap yakni: tahap persiapan, tahap pelaksana, dan tahap evaluasi. Maka berkenaan dengan hal itu disini dikatakan bahwa fase keterlibatan rakyat dalam pemilu kelurahan ubung adalah sangat bersemangat karena nyaris dari 49,41\% pemilih kelurahan ubung yang terdaftar dan daftar Pemilihan Tetap datang ke Tempat Pemungutan Suara untuk menggunakan hak pilihnya.

Kata Kunci: Partisipasi Masyarakat, Pemilihan Umum Serentak, Kelurahan Ubung
\end{abstract}

\begin{abstract}
Election is a series of activities in democratic voting. In this regard, the election is regulated in Law Number 7 of 2017, here it explains how the participation of the people of Ubung Village in the context of participating in the 2019 election process. This study aims to determine the election management system according to Law No. 7 of 2017 and knowing about the implementation of the election in Ubung Village. This type of research is empirical research. This research was carried out by going directly to the research location which was located in the Ubung Village. The results showed that the stages in the people's participation in the kelurahan ubung are: in the election process it can be classified into 3 (three) stages, namely: the preparation stage, the implementation stage, and the evaluation stage. So in this regard here it is said that the phase of people's involvement in the election of the Kelurahan ubung is very enthusiastic because almost $49.41 \%$ of the registered voters of the Kelurahan ubung and the Permanent Election list come to the polling stations to exercise their voting rights.
\end{abstract}

Keywords: Community Participation, Simultaneous General Election, Ubung Urban Village

\section{PENDAHULUAN}

Pemilu adalah memilih seseorang untuk mengisi suatu jabatan politik tertentu, jabatan yang dikatakan tersebut bermacam-macam mulai dari jabatan di tingkat pemerintahan sampai kepala desa, dengan pada konteks yang lebih luas pemilu dapat juga diartikan proses mengisi jabatan-jabatan seperti Ketua OSIS atau ketua kelas. Dengan demikian bahwa disebutkan pemilu merupakan salah satu usaha untuk mempengaruhi rakyat secara tidak memaksa dengan melakukan kegiatan, hubungan publik, komunikasi massa, dan kegiatan lain. Di dalam pelaksana pemilu menyebutkan: bahwa pemilu dilaksanakan berdasarkan pokok yaitu: langsung, umum, bebas, rahasia, jujur, dan adil. Berdasarkan hal tersebut maka kewenangan yang menonjol untuk pemilu adalah kewenangan dari bawah bagi warganegara dan digunakan sesuai dengan kehendak rakyat. Oleh karenanya, pelaksana kedaulatan rakyat tidak dapat dilepaskan dari pemilu, oleh karena pemilu merupakan konsekuensi logis yang menganut prinsip kedaulatan rakyat (demokrasi). Sesuai mandat konstitusi dimana, adapun tanggung jawab dari pada KPU (Komisi Pemilihan Umum):

1. Melaksanakan dan mengkoordinasikan pemilu.

2. Berkompetisi dalam menentukan pemilih.

3. Memberikan batasan daerah pemilihan.

4. Mengesahkan pemilu (Morissan, 2005) 
Penelitian-penelitian serupa pernah dilakukan, salah satunya mengenai partisipasi politik masyarakat dalam pemilihan umum legislatif di Kota Denpasar (Arniti, 2020), selanjutnya mengenai partisipasi masyarakat dalam pemilu 2019 di Kabupaten Kutai Kartanegara (Biru, 2020), dan terakhir mengenai implikasi partisipasi masyarakat pada pilkada serentak dalam meningkatkan demokrasi konstitusional di Indonesia (Lisma \& Tyesta, 2017). Rumusan masalah yang akan didiskusikan dalam penelitian ini berbeda dengan rumusan dan kajian penelitian serupa sebelumnya. Dengan demikian, berdasarkan pemaparan tersebut, penelitian ini didesain untuk menganalisis sistem penyelenggaraan pemilu dan mengetahui proses pelaksanaan pemilu di Kelurahan Ubung.

\section{METODE PENELITIAN}

Penelitian ini menggunakan tipe penelitian empiris (Amiruddin \& Asikin, 2012). Penelitian ini dilakukan dengan menelaah ketentuan normatif yang diterapkan dalam praktek dan sebagai studi kasus atau penelitian hukum yang nondoktrinal, yang bekerja untuk menemukan jawaban-jawaban yang benar dengan pembuktian kebenaran dari fakta-fakta sosial yang sebagaimana terdapat dalam kehidupan sehari-hari. Dan pendekatan masalah yang digunakan dalam penelitian ini adalah pendekatan sosiologis. Adapun bahan yang terdapat bersumber pada (Soekanto \& Mamudji, 2001):

a. Data Primer, yaitu penelitian bertujuan untuk memperoleh data-data langsung dari sumber pertama dilapangan (field research) yaitu dengan melakukan wawancara dengan informan yang ada hubungannya dengan penelitian ini, guna memperoleh data yang akurat.Penelitian ini dilakukan di Kelurahan Ubung.

b. Data Sekunder; data sekunder yaitu data yang diperoleh oleh peneliti dari sumber atau bahan yang sudah ada.

Dalam pengumpulan data, peneliti menggunakan teknik observasi dan wawancara (guide interview). Tujuanntya untuk memperoleh data berkaitan dengan permasalahan hukum yang di bahas. Dengan kata lain, pengumpulan data dilakukan dengan cara studi lapangan. Teknik pengolahan dan analisis data dalam penelitian ini yaitu menggunakan teknik formal yang mana data dideskripsikan melalui kata-kata.

\section{HASIL DAN PEMBAHASAN}

1. Sistem Penyelenggaraan Pemilu

Seperti yang diketahui bahwa lembaga yang berperan penting dalam penyelenggara pemilu antara lain:

1. Komisi Pemilihan Umum (KPU).

2. Badan Pengawas Pemilu (BAWASLU).

3. Dewan Kehormatan Penyelenggara Pemilu (DKPP).

Di dalam penyusunan badan pelaksana pemilu ada banyak hal penting yang harus di perhatikan sebagai berikut.

a. Konstruksi: Suatu kegiatan dalam membangun sarana dan prasarana.

b. Wewenang dan Tanggung Jawab: Hak untuk melakukan sesuatu atau memerintah orang lain untuk melakukan atau tidak melakukan sesuatu agar mencapai tujuan tertentu, bahwa wewenang atau tanggung jawab itu di anugerahkan karena seseorang diberi dilimpahkan atau diwarisi hal tersebut.

c. Konfigurasi: Kekuatan politik yang riil dan eksis dalam suatu sistem poitik.

d. Kedudukan: Tempat atau posisi seseorang dalam menduduki suatu jabatan, serta hak-hak dan kewajibannya.

e. Penyelenggaraan: Kegiatan atau pelaksanaan suatu hal yang dilakukan guna mencapai suatu tujuan tertentu.

f. Kewajiban: Tindakan yang harus di ambil oleh seseorang, baik secara hukum ataupun moral. Di dalam hal ini kewajiban merupakan kendala mereka membatasi kebebasan kita, namun dengan hal ini kita dapat memilih untuk bertindak bebas berdasarkan kewajiban (Sirajuddin \& Winardi, 2015).

Disini dikatakan bahwa adapun tujuan dari pada penyelenggaraan pemilu adalah: Dalam pengertian pemilu disini berarti rakyat dapat melakukan kegiatan memilih orang atau sekelompok orang. Namun 
harus diakui bahwa tujuan pemilu dikatakan dengan berbeda-beda. Berkenaan dengan hal itu dengan demikian maka dapat disimpulkan bahwa pemilu pada dasarnya memiliki empat fungsi utama, yakni:

1. Suatu kebijakan yang di ambil oleh seorang pemimpin.

2. Lembaga legislatif yang menjadi cerminan dalam perwakilan politik.

3. Kelompok orang yang lama dari pusaran utama partai politik; dan

4. Ketatangaraan ilmu politik (Widiati, 2010).

Di dalam sistem penyelenggara pemilu, dikatakan bahwa adapun prinsip- prinsipnya sebagai berikut (Jurdi, 2018):

1. Independen: Tidak memihak kepada salah satu atau punya kekuasaan tersendiri.

2. Jujur: Dalam melaksanakan pemilu kejujuran ini merupakan kunci suksesnya.

3. Benar: Sikap tegas dalam bertindak dan mengambil keputusan secara tepat dan benar.

4. Berkepastian hukum: Salah satu prinsip dalam penyelenggara pemilu.

5. Tertib: Dengan taat pada aturan maka ketertiban dapat diciptakan.

6. Terbuka: Dalam pelaksanaan pemilu tidak diperkenankan menyimpan hal yang ditutupi.

7. Proporsional: Meletakkan sesuatu sesuai dengan hak dan kewajibannya.

8. Professional: Di dalam prinsip professional ini maka pemilu diharapkan untuk diselenggarakan secara professional.

9. Akuntabel: Dipertanggungjawabkan sesuai dengan peraturan perundang-undangan yang berlaku.

10. Positif: Bahwa pemilu sebagai suatu rangkaian proses dapat di selenggarakan secara psitif.

11. Efisien: Tepat atau sesuai untuk mengerjakan (menghasilkan) sesuatu.

\section{Partisipasi Masyarakat dalam Pemilihan Umum Serentak di Kelurahan Ubung}

Dari data yang di olah pada profil Kelurahan Ubung, sebagian besar dari keseluruhan jumlah warga merupakan warga dengan kelompok umur 18-56 tahun. Pendidikan yang paling banyak ditempuh di kelurahan ini adalah tingkat pendidikan SMA/sederajat. Di kelurahan ini terdapat 15 sekolah yang terdiri dari 5 TK, 5 SD, 3 SMP, dan 2 SMA. Keberadaan sekolah ini tentu akan memberikan kesadaran bagi masyarakat sekitar untuk meningkatkan jenjang pendidikannya. Warga Kelurahan Ubung adalah setiap warga yang berada dan masuk dalam keanggotaan empat banjar yang ada di wilayah kelurahan ubung. Jumlah warga yang terdata tahun 2018 adalah 7.516 orang dari 2 . $106 \mathrm{KK}$, dimana jumlah penduduk laki-laki yaitu 4.766 orang dan perempuan 2.750 orang. Kelurahan Ubung merupakan salah satu kelurahan yang ada di Kecamatan Denpasar Utara, Kotamadya Denpasar, Provinsi Bali. Adapun letak geografis Kelurahan Ubung yaitu:

1) Sebelah utara: Desa Ubung Kaja, Kecamatan Denpasar Utara.

2) Sebelah Selatan: Desa Pemecutan Kaja, Kecamatan Denpasar Utara.

3) Sebelah Timur: Kelurahan Peguyangan, Kecamatan Denpasar Utara.

4) Sebelah Barat: Desa Padang Sambian Kaja, Kecamatan Denpasar Barat.

Kelurahan ubung ini memiliki jumlah penduduk yang banyak, baik kelompok remaja, dewasa dan lansia. Dengan hal itu Kelurahan Ubung mempunyai luas 173.000 Ha. Sebagian besar merupakan daerah pemukiman, sebagian kecilnya merupakan sawah irigrasi teknis dan prasarana umum. Kelurahan Ubung ini memiliki iklim laut tropis yang dipengaruhi oleh angin musim, terdapat musim kemarau dan musim hujan yang diselingi oleh musim pancaroba. Suhu rata-rata harian di Desa Ubung 32C. Terkait dengan administrasi pemerintah, wilayah Kelurahan Ubung terbagi ke dalam empat dusun. Adapun empat dusun tersebut antara lain:

1) Dusun Sedana Merta

2) Dusun Tengah

3) Dusun Sari

4) Dusun Batur

Dengan demikian, sehingga terdapat banyak pemilih pada tahun 2019 di Kelurahan Ubung, karena terdapat 5 jenis Surat suara dalam satu TPS tentunya akan membuat para pemilih memiliki pemahaman yang kurang mengenai tata cara pencoblosan yang baik dan benar. Di dalam proses pelaksanaan pemilu yang diselenggarakan di Kelurahan Ubung maka adapun 3 (tiga) tahap yang dapat dilakukan antara lain:

1) Tahap Persiapan: Dimana dalam tahap ini maka tahap persiapan dikatakan bahwa sebelum dilaksanakannya pemilu. 
2) Tahap Pelaksana: Dalam tahapan ini maka tahap pelaksanaan dikatakan dalam proses berjalannya atau berlangsungnya pemilu.

3) Tahap Evaluasi: Tahap evaluasi ini merupakan tahap dimana sangat diperlukan keterlibatan atau peran serta masyarakat khususnya di kelurahan ubung.

Dari proses pelaksanaan pemilu yang disampaikan diatas maka adapun penelitian yang dapat dilakukan di Kelurahan Ubung mengenai bentuk-bentuk keikutsertaan rakyat dengan pemilu. Adapun bentuk-bentuk partisipasinya antara lain:

1. Sosialisasi ke pemilih di Kelurahan Ubung: Dalam kegiatan sosialisasi ini adanya beberapa dari masyarakat yang tidak menggunakan hak pilihnya atau golput, maka dari itu dengan sosialisasi yang dilakukan diharapkan dapat meningkatkan partisipasi masyarakat dalam menggunakan hak pilihnya yang di dorong oleh semangat tinggi guna menciptakan pemilu damai.

2. Membantu administrasi dalam kepemiluan: Dalam adanya kegiatan pemilu ini tentu adanya banyak berkas-berkas yang harus dikerjakan dan diselesaikan masing-masing kelurahan, dengan kegiatan proses administrasi tersebut maka akan membantu dalam administrasi yang menunjang tentang kepemiluan.

3. Mengawasi proses berjalannya pemilu: Keamanan proses berjalannya pemilu adalah salah satu hal yang harus terjamin keberadaannya. Karena jika keamanan proses pemilu terjamin, maka situasi kondusif, teratur, aman, dan lancar.

4. Melakukan kegiatan bakti sosial di keluarahan ubung: Dalam kegiatan bhakti sosial ini maka kita bisa meningkatkan perilaku hidup bersih dan asri serta mempererat hubungan antar masyarakat, khusunya masyarakat di kelurahan ubung.

Untuk mengetahui bagaimana bentuk partisipasi masyarakat dalam pemilihan umum yang dilaksanakan tepatnya di Kelurahan Ubung dalam pelaksanaan pemilu serentak tahun 2019, maka peneliti mengadakan wawancara sebagai berikut: "Menurut Bapak I Wayan Ariyanta Selaku Kepala Kelurahan Ubung, mengatakan bahwa: Pemilu serentak yang dilaksanakan pada bulan April tahun 2019 ini sangat bermanfaat bagi para kaum generasi muda. Dimana dalam adanya pelaksanaan pemilu serentak ini selain dalam pendidikan, pemilu serentak sangatlah penting bagi pemula muda untuk mengajarkan kesanggupan rasa percaya diri untuk terjun langsung ke dalam dunia politik". "Menurut Bapak Agung Surya Selaku Ketua KPU mengatakan bahwa: jumlah pemilih golput dalam pemilu serentak di kelurahan ubung adalah mencapai angka 1311, dan suara tidak sah mencapai 94 suara, jadi keseluruhan suara sahnya adalah 97, 11\%. Di dalam pemilu serentak yang dilakukan pada tahun 2019 ini maka saya selaku Ketua KPU menegaskan bahwa khususnya untuk di wilayah kelurahan ubung harus di tingkatkan lagi partisipasinya, supaya tidak ada yang golput atau tidak memilih". Menurut (Sahbana, 2017), golput merupakan hal yang tidak dilarang oleh pemerintah Indonesia, berbeda dengan Negara-negara maju, warga Negara yang tidak mau menggunakan hak pilihnya akan dikenakan sanksi. "Menurut Bapak Yudik Setiawan Selaku Ketua KPPS mengatakan bahwa: Masyarakat yang berada khususnya di Kelurahan Ubung, sangat antusias dalam berpartisipasi berpolitik. Di Kelurahan Ubung ini tingkat partisipasinya mencapai 49, 41\%, saya selaku Ketua KPPS di Kelurahan Ubung mengharapkan semoga pemilu yang akan diadakan pada masa yang akan datang, agar lebih meningkatkan lagi tingkat partisipasinya”.

\section{SIMPULAN DAN SARAN}

\section{Simpulan}

Adapun simpulan yang dapat ditarik dari penjelasan di atas bahwa di dalam sistem penyelenggaraan pemilu, bahwa sistem pemilu dapat diklasifikasikan menjadi dua bagian yaitu: sistem pemilihan organis dan sistem pemilihan mekanis. Berkenaan dengan hal itu, maka dalam sistem mekanis dapat dilakukan dengan dua cara, yaitu sistem perwakilan atau pemilihan distrik dan sistem perwakilan proporsional. Pada sistem perwakilan proporsional dibedakan lagi atas beberapa varian yakni: daftar terbuka dan daftar tertutup. Kemudian, dalam proses pemilihan pemilu maka dapat diklasifikasikan menjadi 3 (tiga) tahap yakni: tahap persiapan, tahap pelaksana, dan tahap evaluasi. Maka berkenaan dengan hal itu disini dikatakan bahwa fase keterlibatan rakyat dalam pemilu kelurahan ubung untuk memberikan suara, sangat antusias karena hampir dari $49,41 \%$ pemilih kelurahan ubung yang terdaftar dan Daftar Pemilihan Tetap datang ke Tempat Pemungutan Suara untuk menggunakan hak pilihnya. Maka dari itu berdasarkan demografi Kelurahan Ubung yang mewilayahi terminal ubung 
sebagaimana banyaknya pendatang yang datang ke Bali, sehingga banyak terdapat warga yang tidak terdaftar dalam Daftar Pemilih Tetap, melainkan masuk ke dalam Daftar Pemilih Khusus. Terdapat beberapa syarat yang harus dipenuhi pemilih untuk bisa masuk ke dalam Daftar Pemilih Khusus yaitu harus mengurus terlebih dahulu surat A5 di kantor pemilihan umum. Maka dari itu peneliti beserta pihak dari Kelurahan Ubung melakukan kegiatan sosialisasi kepada warga Kelurahan Ubung dan BIMTEK kepada setiap KPPS untuk meningkatkan pengetahuan mengenai tata cara pemilu di tahun 2019 ini sehingga terwujudnya pemilu yang damai tentram dan sejahtra.

\section{Saran}

Hendaknya pemerintah dalam hal ini harus bertindak tegas dalam menangani sistem berjalannya pemilihan umum (pemilu) dengan mengingat masih banyak adanya kecurangan dalam sistem pencoblosan, dengan itu kita harus bersama-sama untuk mengurangi tingkat kecurangan dalam sistem pencoblosan tersebut yang telah dilakukan oleh oknum-oknum yang tidak baik. Maka dengan ini pelaksanaan pemilu diharapkan mampu dengan memberikan informasi secara jelas dan benar terhadap proses berjalannya pemilu dengan baik dan lancar. Kemudian, dapat menyempurnakan program mahasiswa yang telah dilaksanakan dan melanjutkan program-program yang sifatnya berkelanjutan, program-program yang telah dilaksanakan diharapkan dapat diteruskan dan dikembangkan serta dimanfaatkan untuk kepentingan masyarakat setempat. Serta pentingnya partisipasi pemerintah dengan masyarakat di kelurahan ubung, dalam keikutsertaan proses pemilu serentak tahun 2019 yang diharapkan berjalannya prosedur pemilihan umum dengan baik dan benar.

\section{DAFTAR PUSTAKA}

Amiruddin, \& Asikin, Z. (2012). Pengantar Metode Penelitian Hukum (6th ed.). Jakarta: Raja Grafindo Persada. Arniti, N. K. (2020). Partisipasi Politik Masyarakat dalam Pemilihan Umum Legislatif di Kota Denpasar. Jurnal Ilmiah Dinamika Sosial, 4(2).

Biru, M. I. R. (2020). Partisipasi Masyarakat dalam Pemilu 2019 di Kabupaten Kutai Kartanegara. EJournal Ilmu Pemerintahan, 8(2).

Jurdi, F. (2018). Pengantar Hukum Pemilihan Umum. Jakarta: Kencana Prenadamedia Group.

Lisma, \& Tyesta, L. (2017). Implikasi Partisipasi Masyarakat pada Pilkada Serentak dalam Meningkatkan Demokrasi Konstitusional di Indonesia (Studi Terhadap Pelaksanaan Pilkada Serentak di Provinsi Sulawesi Selatan Tahun 2015). Jurnal Law Reform, 13(1).

Morissan. (2005). Hukum Tata Negara RI Era Reformasi. Jakarta: Ramdina Prakarsa.

Sahbana. (2017). Partisipasi Masyarakat dalam Pelaksanaan Pemilihan Umum. Jurnal Warta, (51).

Sirajuddin, \& Winardi. (2015). Dasar-Dasar Hukum Tata Negara. Malang: Setara Pers.

Soekanto, S., \& Mamudji, S. (2001). Penelitian Hukum Normatif. Jakarta: PT. Raja Grafindo Persada.

Widiati, I. A. P. (2010). Penyelenggaraan Pemilihan Umum di Indonesia. Kertha Wicaksana, 16(1). 